\title{
Solubility and Leaching Risks of Organic Carbon in Paddy Soils as Affected by Irrigation Managements
}

\author{
Junzeng Xu, ${ }^{1,2}$ Shihong Yang, ${ }^{1}$ Shizhang Peng, ${ }^{1}$ Qi Wei, ${ }^{1}$ and Xiaoli Gao ${ }^{1,2}$ \\ ${ }^{1}$ State Key Laboratory of Hydrology-Water Resources and Hydraulic Engineering, Hohai University, Nanjing 210098, China \\ ${ }^{2}$ College of Water Conservancy and Hydropower Engineering, Hohai University, Nanjing 210098, China \\ Correspondence should be addressed to Shizhang Peng; szpeng@hhu.edu.cn
}

Received 29 April 2013; Accepted 13 June 2013

Academic Editors: C. García, P. F. Hudak, and M. D. Mingorance Alvarez

Copyright (c) 2013 Junzeng Xu et al. This is an open access article distributed under the Creative Commons Attribution License, which permits unrestricted use, distribution, and reproduction in any medium, provided the original work is properly cited.

\begin{abstract}
Influence of nonflooding controlled irrigation (NFI) on solubility and leaching risk of soil organic carbon (SOC) were investigated. Compared with flooding irrigation (FI) paddies, soil water extractable organic carbon (WEOC) and dissolved organic carbon (DOC) in NFI paddies increased in surface soil but decreased in deep soil. The DOC leaching loss in NFI field was $63.3 \mathrm{~kg} \mathrm{C}^{-1}$, reduced by $46.4 \%$ than in the FI fields. It indicated that multi-wet-dry cycles in NFI paddies enhanced the decomposition of SOC in surface soils, and less carbon moved downward to deep soils due to less percolation. That also led to lower SOC in surface soils in NFI paddies than in FI paddies, which implied that more carbon was released into the atmosphere from the surface soil in NFI paddies. Change of solubility of SOC in NFI paddies might lead to potential change in soil fertility and sustainability, greenhouse gas emission, and bioavailability of trace metals or organic pollutants.
\end{abstract}

\section{Introduction}

Dissolved organic carbon (DOC) in soil, which is present in soil solution and interacts with colloids and clays, plays an important role in soil carbon cycling $[1,2]$. It is highly related to the greenhouse gas $\left(\mathrm{CO}_{2}\right.$ and $\left.\mathrm{CH}_{4}\right)$ emissions [3$5]$, nutrient availability $[6,7]$, as well as the mobilization, translocation, and toxicity of several inorganic and organic pollutants in soil [8-13]. The DOC losses from soil ecosystems, via leaching or surface runoff, account for numerous pollution problems of surface water and groundwater [14, 15]. Agricultural practices impact the timing and magnitude of DOC export from soils to rivers or ditches [16-18]. However, information on the effects of agricultural practices on soil DOC leaching is still limited, although it is a crucial component of the ecosystem carbon balance [19-22].

Rice is one of the most important crops in the Asian monsoon region [23]. The rice field ecosystem is commonly characterized by flooding conditions and high percolation rate. A great deal attention is paid to nitrogen and phosphorus with regard to leaching risks of nutrients in rice fields [24-28]. Leaching loss of DOC from paddy soil, which is relatively rich in organic matter, is always overlooked. With increasing water scarcity, water saving irrigation techniques, such as nonflooding controlled irrigation (NFI), alternate dry-wet irrigation (AWDI), and the rice intensification (SRI) system, are applied widely [29-33]. Soil wetting and drying cycles influence a large number of biological and chemical processes [34-37]. Solubility of soil organic carbon (SOC) and its leaching risks will change when the rice field is exposed to nonflooding conditions under water-saving irrigation management.

In the present study, water extractable organic carbon (WEOC) contents in soils and DOC in soil solutions, as well as DOC leaching risks, were measured in rice paddies under different irrigation managements to reveal the influence of NFI on soil DOC dynamics.

\section{Materials and Methods}

2.1. Site Description and Experimental Design. The study was conducted in rice paddies at the Kunshan irrigation and drainage experiment station $\left(31^{\circ} 15^{\prime} 15^{\prime \prime} \mathrm{N} 120^{\circ} 57^{\prime} 43^{\prime \prime} \mathrm{E}\right)$ in the Tai Lake region in China. The study area has a subtropical monsoon climate, with an average annual air temperature of $15.5^{\circ} \mathrm{C}$ and a mean annual precipitation of $1,097.1 \mathrm{~mm}$. The paddy soil is Gleyic-Stagnic Anthrosols, developed from 
TABLE 1: Limits for irrigation in different stages of rice for non-flooding controlled irrigation.

\begin{tabular}{|c|c|c|c|c|c|c|c|c|c|}
\hline \multirow{2}{*}{ Stages } & \multirow{2}{*}{ Regreening } & \multicolumn{3}{|c|}{ Tillering } & \multicolumn{2}{|c|}{ Jointing and booting } & \multirow{2}{*}{$\begin{array}{l}\text { Heading and } \\
\text { flowering }\end{array}$} & \multirow{2}{*}{ Milk maturity } & \multirow{2}{*}{ Yellow maturity } \\
\hline & & Former & Middle & Later & Former & Later & & & \\
\hline Upper limit & $30 \mathrm{~mm}$ & $\theta s_{1}$ & $\theta s_{1}$ & $\theta s_{1}$ & $\theta s_{2}$ & $\theta s_{2}$ & $\theta s_{3}$ & $\theta s_{3}$ & \multirow{2}{*}{ Drying } \\
\hline Lower limit & $10 \mathrm{~mm}$ & $0.7 \theta s_{1}$ & $0.65 \theta s_{1}$ & $0.6 \theta s_{1}$ & $0.7 \theta s_{2}$ & $0.75 \theta s_{2}$ & $0.8 \theta s_{3}$ & $0.7 \theta s_{3}$ & \\
\hline Monitored soil depth $(\mathrm{cm})$ & - & $0-20$ & $0-20$ & $0-20$ & $0-30$ & $0-30$ & $0-40$ & $0-40$ & - \\
\hline
\end{tabular}

$\theta s_{1}, \theta s_{2}$, and $\theta s_{3}$ are the saturated water content of the soil in different stages of rice.

alluvial deposits. The soil texture in the plowed layer (0$20 \mathrm{~cm}$ ) is clay, with a total nitrogen content of $1.03 \mathrm{~g} \mathrm{~kg}^{-1}$, total phosphorus content of $1.35 \mathrm{~g} \mathrm{~kg}^{-1}$, total potassium content of $20.8 \mathrm{~g} \mathrm{~kg}^{-1}$, and $\mathrm{pH}$ of 7.4 (soil : water $=1: 2.5$ by weight). SOC contents for soil depths of $0-10,10-20,20-40$, and $40-$ $60 \mathrm{~cm}$ are $13.8,12.1,11.4$, and $10.3 \mathrm{~g} \mathrm{~kg}^{-1}$; soil bulk densities are $1.28 \mathrm{~g}, 1.33^{3}, 1.36$, and $1.35 \mathrm{~g} \mathrm{~cm}^{-3}$, respectively. The saturated soil water contents $(\mathrm{v} / \mathrm{v})$ for the layers of $0-20,0-30$, and $0-$ $40 \mathrm{~cm}$ are 52.4, 49.7, and $47.8 \%$, respectively. The cropping system used is a rice-wheat rotation system. Winter wheat was harvested on 16-17 May before the experiment. The wheat straw was removed, whereas the root and about $10 \mathrm{~cm}$ stubble were buried by plowing. The variety of rice planted was Japonica Rice NJ46. The rice was transplanted with $13 \mathrm{~cm} \times$ $25 \mathrm{~cm}$ hill spacing on 23 June, and harvested on 26 October in 2009.

Two irrigation treatments were used, namely, flooding irrigation (FI) and nonflooding controlled irrigation (NFI). A randomized complete block design and three replications were established in 6 plots $(5 \mathrm{~m} \times 7 \mathrm{~m})$. The adjacent plots were separated by plastic membrane which was inserted into the ridges at a depth of $500 \mathrm{~mm}$, to isolate the water within different plots and avoid hydraulic exchange between adjacent plots. In the FI rice fields, a depth of $3-5 \mathrm{~cm}$ standing water was always maintained after transplanting, except when drying in the later tillering and yellow maturity periods. In the NFI rice fields, standing water depth was kept between 5 and $25 \mathrm{~mm}$ during the first $7-8$ days after transplanting (DAT) in regreening period; irrigation was applied only to keep soil saturated in other stages. Standing water was avoided in other stages, except during rain harvesting period and the pesticide or fertilizer application period. Table 1 presents the root zone soil water content criteria in different growth stages. The same fertilizer doses for each split were applied into each plot according to the local conventional fertilizer application method.

2.2. Field Measurements. Irrigation water volumes were recorded by water meters installed on the pipes. Soil moisture in rice field was monitored with three replications using a time domain reflectometer (TDR, soil moisture, USA) and with $20 \mathrm{~cm}$ waveguides installed at $0-20,20-40$, and $40-$ $60 \mathrm{~cm}$ depths. Water layer depth was monitored using a vertical ruler fixed in the field. Daily meteorological data, including precipitation volume, wind speed, temperature (maximum, minimum, and average), sunshine duration, and relative humidity, were recorded by an automatic weather station (ICT, Australia). Soil temperature and soil redox potentials (Eh) at $5 \mathrm{~cm}$ depth were measured using mercury thermometers and oxidation-reduction potential meters, with three replications in situ. Rice was harvested on 26 October 2009, and yield was determined for each plot.

2.3. Soil Sampling and WEOC Contents Measurement. Soil samples were collected during the rice season with a hand auger for soil WEOC measurement. The sampling was conducted at five locations for each treatment plot at five depths, 0-10, 10-20, 20-30, 30-40, and 40-60 cm. Then fresh samples of the same depth in each plot were homogenized by mixing and separated from debris and crop residues. Five grams of fresh soil samples were then extracted in distilled water (soil: water $=1: 10$ by weight) on a shaker for $60 \mathrm{~min}$. DOC in the extract was determined using a TOC-1020 A analyzer (Elementar, High TOC II, Germany). Using the same method, soil samples were collected at pretransplanting and postharvesting periods in depths of $0-10,10-20,20-40$, and $40-60 \mathrm{~cm}$ for SOC measurement. Ten grams of fresh soil samples were selected for SOC measurement using the potassium dichromate oxidation method, with $0.8 \mathrm{~mol} \mathrm{~L}^{-1}$ $\mathrm{K}_{2} \mathrm{Cr}_{2} \mathrm{O}_{4}-\mathrm{H}_{2} \mathrm{SO}_{4}$ solution at $170-180^{\circ} \mathrm{C}$ (oil bath) [38]. Soil samples moisture contents were determined using an ovendried method, and WEOC and SOC contents were calculated as milligram $\mathrm{C}$ per gram dry soil. Change in SOC storage was calculated based on the values obtained at pretransplant and at harvest.

\subsection{Soil Solution Sampling and DOC Contents Measurement.} Ceramic suction cups $(2 \mathrm{~cm}$ in inner diameter and $7 \mathrm{~cm}$ in length) with numerous pores (about $2 \mu \mathrm{m}$ in diameter) were installed vertically at $7-14 \mathrm{~cm}, 27-34 \mathrm{~cm}$, and $47-54 \mathrm{~cm}$ depths to collect soil solutions with three replications. To acquire a field-equilibrated status and eliminate the sorb of DOC by suction cups [39], the cups, which were cleaned by 0.1 molar $\mathrm{HCl}$ and deionised water, were installed firmly into the soil one year ago in June 2008 [28]. The clay suction cup was embedded in a polyvinyl chloride pipe, allowing the water to be pumped out. Soil solutions were collected and stored in $100 \mathrm{~mL}$ polytetrafluoroethylene bottles and then taken to the laboratory immediately. DOC contents in the soil solutions were determined using the TOC-1020 A analyzer.

2.5. Leaching Loss of DOC. Seasonal DOC leaching losses were calculated based on DOC contents in $47-54 \mathrm{~cm}$ soil solutions and deep percolation (DP) rate. Daily DP was 


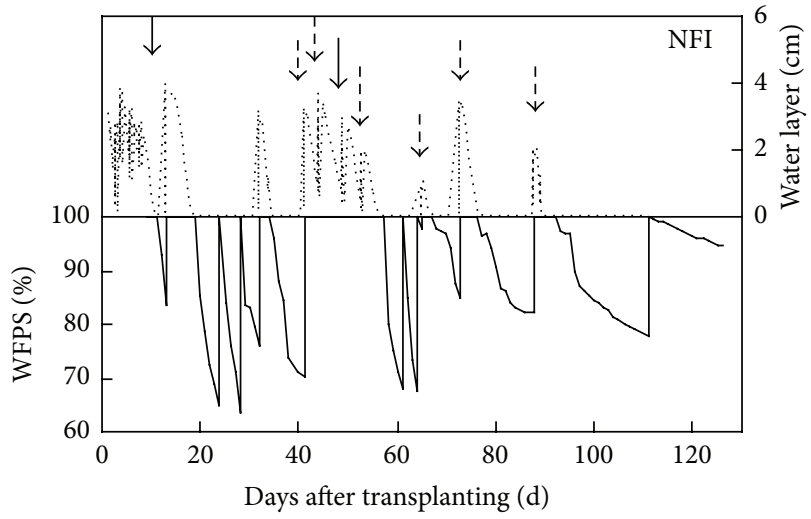

(a)

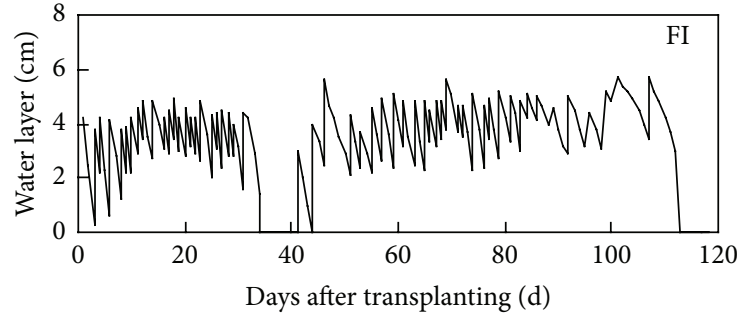

(b)

FIGURE 1: Water depth and soil moisture in FI and NFI rice fields (solid and dashed arrows denote irrigations for fertilizer and pesticides application in NFI rice fields).

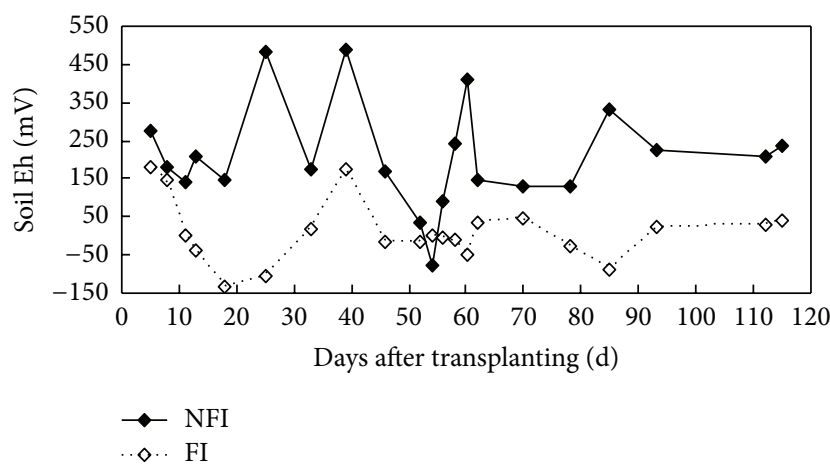

(a)

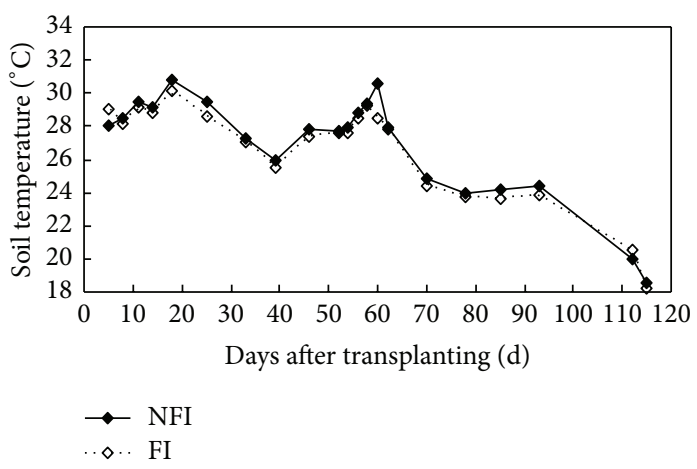

(b)

FIGURE 2: Seasonal variation of soil Eh and soil temperature at $5 \mathrm{~cm}$ depth in rice fields under different water managements.

calculated by following the water balance principle based on field measurements:

$$
\mathrm{DP}_{t}=W_{t-1}-W_{t}+I_{t}+P_{t}-D_{t}-\mathrm{ET}_{t}
$$

where DP is the volume of the percolation water, $W$ is the flooding depth or the soil water content in the root zone. $I$, $P$, and $D$ are the water volumes of irrigation, precipitation, and drainage, respectively. ET is the evapotranspiration, which was calculated using the water balance principle based on measurement in bottom-sealed lysimeters (nonweighted, $40 \mathrm{~cm}$ in diameter and $60 \mathrm{~cm}$ in depth with 4 rice hills) with the same irrigation management as the plot.

\section{Results}

3.1. Water Regimes and Soil Characteristics. Eleven wet-dry cycles were observed in NFI fields, with more than 72 days of nonflooding (Figure 1). About two-thirds of the total growth season was nonflooding in the NFI fields, which was much longer than those reported in zero-drainage or alternate wetting and drying irrigation rice fields [40, 41]. Multi-wetdry cycles led to huge change in soil properties in the NFI fields. Soil redox potentials (Eh) at $5 \mathrm{~cm}$ depth ranged from
-77.9 to $+488.9 \mathrm{mV}$ in the NFI fields, much higher than those in the FI fields (from -134.43 to $+181.86 \mathrm{mV}$ ) (Figure 2). Drying in the NFI fields was always accompanied by a rapid increase in Eh values, whereas rewetting caused a sharp decrease. Soil $\mathrm{Eh}$ at $5 \mathrm{~cm}$ depth increased from a negative value to as high as $+480 \mathrm{mv}$ in the NFI fields (25 DAT and 39 DAT). In the FI paddies, midseason drainage also led to a significant $\mathrm{Eh}$ increase, from -104.1 to $+131.1 \mathrm{mV}$ (33-39 DAT). Soil temperatures at $5 \mathrm{~cm}$ depth were slightly higher in the NFI fields than those in the FI fields during most of the rice season (Figure 2).

3.2. Rice Yields and Water Consumption. Evapotranspiration and percolation were 404.6 and $368.8 \mathrm{~mm}$ in the NFI fields, which were reduced by 111.7 and $276.8 \mathrm{~mm}$ compared with the FI treatment (Table 2). Irrigation volumes in the NFI and FI fields were 233.3 and $635.9 \mathrm{~mm}$, whereas water consumption volumes were 773.4 and $1,161.9 \mathrm{~mm}$, respectively. Irrigation volumes and water consumption in the NFI fields were reduced by 63.3 and $33.4 \%$, compared with the FI fields. Rice yield for the NFI treatment was $10,335.8 \mathrm{~kg} \mathrm{ha}^{-1}$; it was the same as the yield for FI treatment $\left(9,889.7 \mathrm{~kg} \mathrm{ha}^{-1}\right)$. Water use efficiency greatly increased in the NFI paddies due to the 


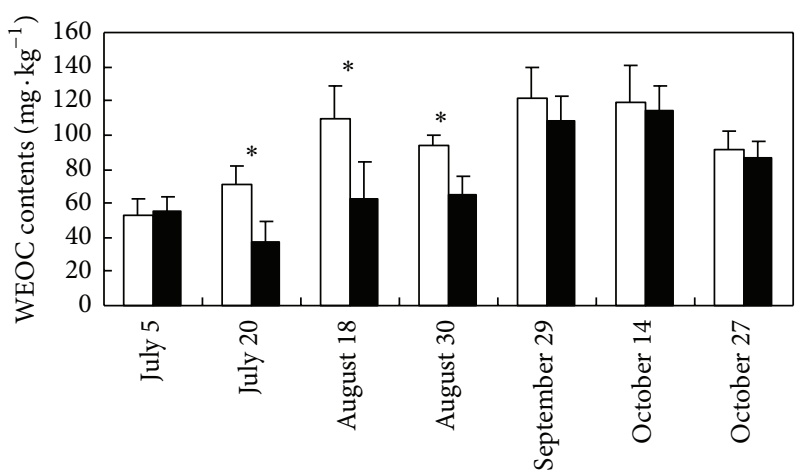

(a) $0-10 \mathrm{~cm}$

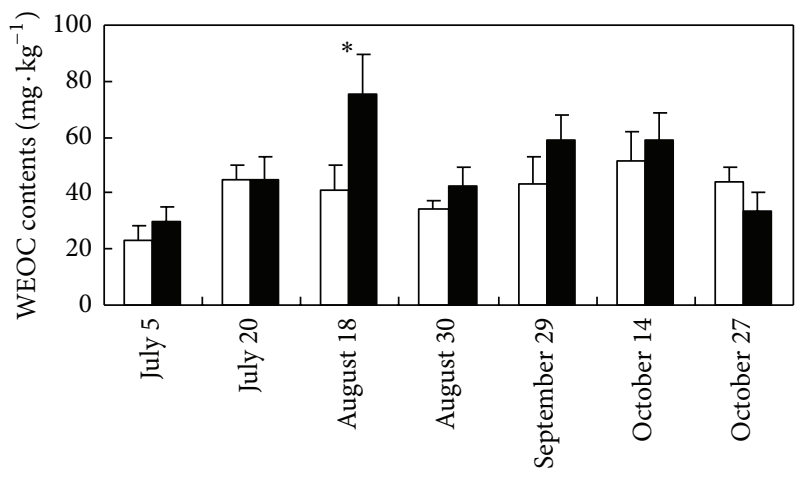

(c) $20-30 \mathrm{~cm}$

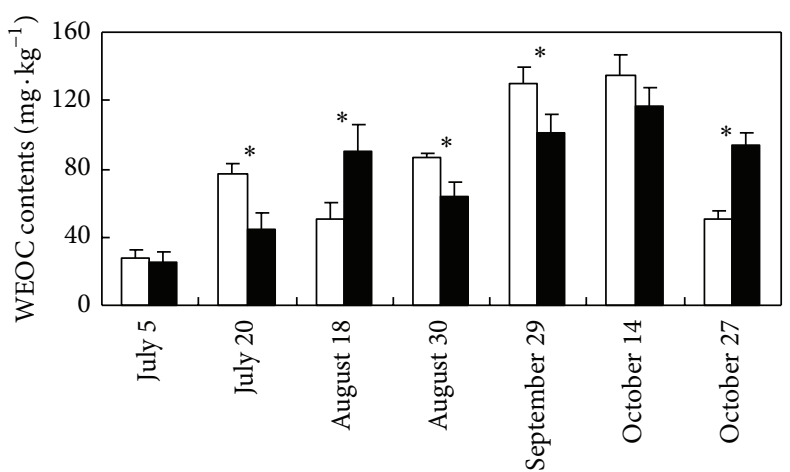

(b) $10-20 \mathrm{~cm}$

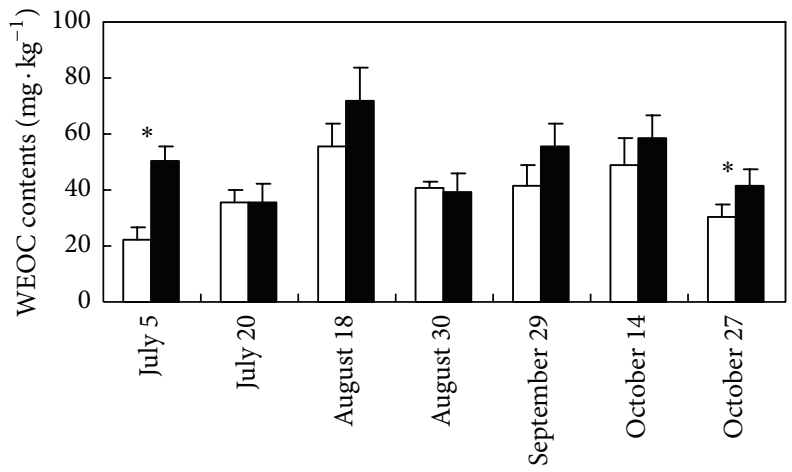

(d) $30-40 \mathrm{~cm}$

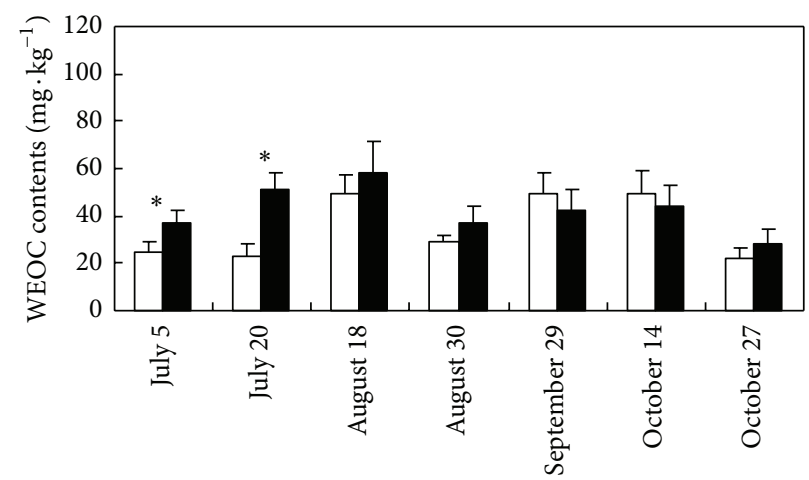

$\square$ NFI

a FI

(e) $40-60 \mathrm{~cm}$

FIGURE 3: Water extractable organic carbon (WEOC) contents in paddy soils under different irrigation managements $\left({ }^{*}\right.$ indicates difference between NFI and FI that is significant at $P<0.05)$.

large reduction in water consumption and irrigation volume. It indicated that NFI is able to get the same yield as FI with a lower cost irrigation and higher water use efficiency than FI.

3.3. Soil WEOC Contents. Soil WEOC contents in both FI and NFI fields at different stages decreased with the increase of soil depth (Figure 3 ). Soil WEOC contents were more variable in the top $0-20 \mathrm{~cm}$ soils than in the $30-40 \mathrm{~cm}$ and $40-60 \mathrm{~cm}$ soils. Soil WEOC contents were always high in the middle stage, when the crop growth and agronomic activities were intensive. Soil WEOC contents at 0-10, 10-20, 20-30, $30-40$, and $40-60 \mathrm{~cm}$ depths varied in the range of 52.4-121.0,
27.4-134.5, 23.5-51.3, 22.2-55.8, and 22.2-49.7 $\mathrm{mg} \mathrm{C} \mathrm{kg}^{-1}$ in the NFI fields, whereas those in the FI fields varied in the range of 37.7-114.0, 25.0-116.5, 29.6-75.6, 35.3-71.7, and 28.4$58.0 \mathrm{mg} \mathrm{C} \mathrm{kg}^{-1}$. But the WEOC contents in the NFI and FI fields were lower than the results obtained by Zhan et al. (2010) [42] in paddy soils (0.44-0.83 $\mathrm{g} \mathrm{C} \mathrm{kg}^{-1}$ ) in Hubei China.

WEOC contents in surface soils at $0-10$ and $10-20 \mathrm{~cm}$ depths in the NFI fields were mostly significantly higher than those in the FI fields. However, WEOC contents in the NFI fields were frequently lower than in FI fields in deep soils at $20-30,30-40$, and $40-60 \mathrm{~cm}$ depths, but only a few results 
TABLE 2: Rice yields and water consumption under different irrigation managements.

\begin{tabular}{lccccc}
\hline Treatment & Yield & Irrigation & Evapotranspiration & Water consumption & Deep seepage \\
$\mathrm{Kg} \mathrm{ha}^{-1}$ & $\mathrm{~mm}$ & $\mathrm{~mm}$ & $7 \mathrm{~mm}^{\mathrm{a}}$ & $7^{\mathrm{a}}$ \\
\hline NFI & $10335.8^{\mathrm{a}}$ & $233.3^{\mathrm{a}}$ & $404.6^{\mathrm{a}}$ & $1161.9^{\mathrm{b}}$ & $368.8^{\mathrm{a}}$ \\
FI & $9889.7^{\mathrm{a}}$ & $635.9^{\mathrm{b}}$ & $516.3^{\mathrm{b}}$ & $634.7^{\mathrm{b}}$ \\
\hline
\end{tabular}

Different letters in each column represent significant difference between the treatments at $P=0.05$ by $t$-test.

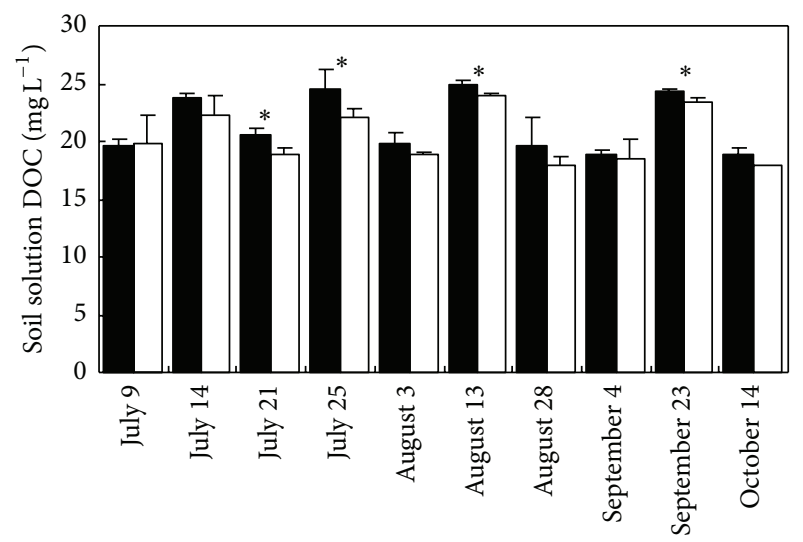

(a) $7-14 \mathrm{~cm}$

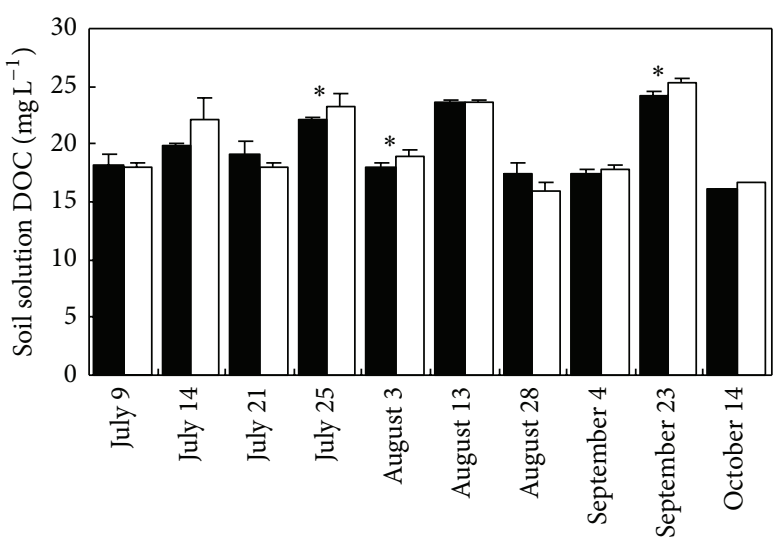

(b) $27-34 \mathrm{~cm}$

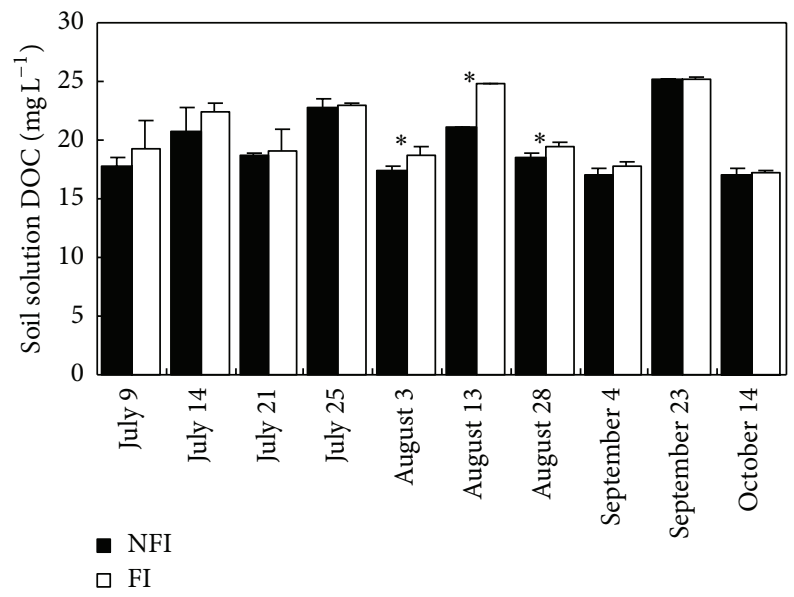

(c) $47-54 \mathrm{~cm}$

FIGURE 4: Dissolved organic carbon (DOC) concentrations in paddy soil solutions at different depths under different irrigation managements $\left({ }^{*}\right.$ indicates difference between NFI and FI that is significant at $\left.P<0.05\right)$.

are significantly lower. Soil WEOC contents at $0-10 \mathrm{~cm}$ and $10-20 \mathrm{~cm}$ depths in the NFI fields increased by an average of $18.5 \mathrm{mg} \mathrm{C} \mathrm{kg}^{-1}$ (24\%) and $2.7 \mathrm{mg} \mathrm{C} \mathrm{kg}^{-1}$ (4\%) compared with those in the FI fields. Soil WEOC contents at 20-30, $30-40$, and $40-60 \mathrm{~cm}$ depths in the NFI fields decreased by $8.7 \mathrm{mg} \mathrm{C} \mathrm{kg}^{-1}$ (18\%), $11.0 \mathrm{mg} \mathrm{C} \mathrm{kg}^{-1}$ (22\%), and $7.3 \mathrm{mg} \mathrm{C} \mathrm{kg}^{-1}$ (17\%). Therefore, the long duration of nonflooding aerobic condition and multi wet-dry cycles in NFI enhanced the soil organic decomposition and mineralization at $0-20 \mathrm{~cm}$ depth.

\subsection{DOC Concentrations in Soil Solutions. DOC concentra-} tions of soil solutions were slightly higher in surface soils than in deep soils (Figure 4). Compared with FI soils, DOC concentrations in soil solutions at 7-14 cm depth in NFI paddies were slightly higher, which increased by $0.81-2.49 \mathrm{mg} \mathrm{L}^{-1}$. The DOC concentrations in soil solutions further confirm that long duration of nonflooding aerobic condition and wetdry cycles in NFI enhanced the soil organic decomposition and mineralization in surface soils. DOC concentrations in NFI soil solutions at $47-54 \mathrm{~cm}$ depth decreased slightly by $0.05-3.61 \mathrm{mg} \mathrm{L}^{-1}$ compared with those in FI paddies, because the decreased percolation led to less carbon moving downward to deep soils. However, the DOC concentrations in NFI soil solutions at $27-34 \mathrm{~cm}$ depth were highly variable, sometimes higher than those in FI and sometimes lower. But generally there is no significant difference between DOC concentrations in NFI and FI fields, with only a few number of differences are significant between the two treatments. 


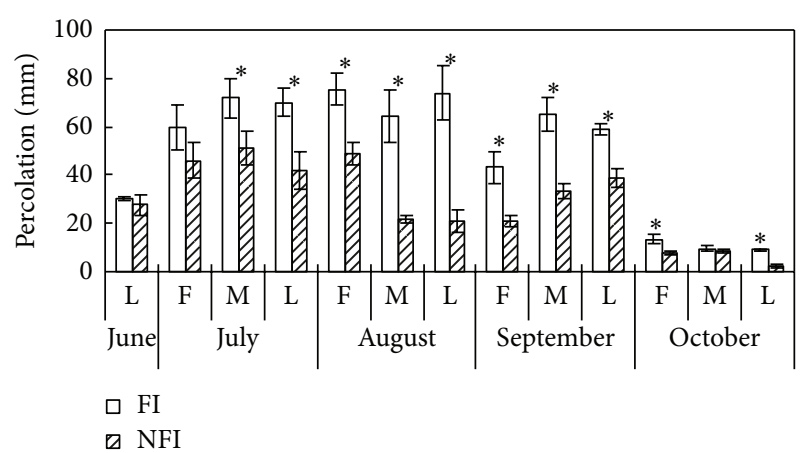

FIGURE 5: Percolation volumes from paddy soils under different irrigation managements $\left({ }^{*}\right.$ indicates difference between NFI and FI that is significant at $P<0.05$ ).

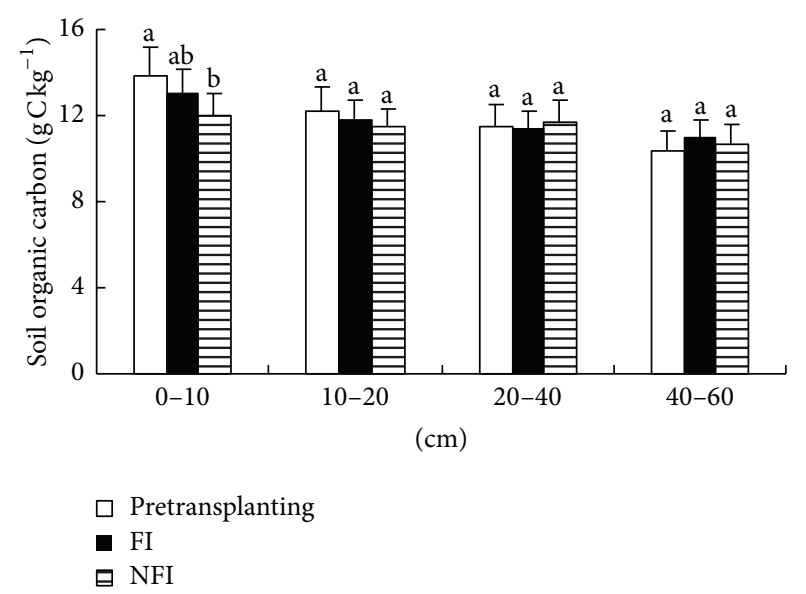

FIGURE 6: Soil organic carbon (SOC) contents in paddy soils under different irrigation management (pretransplanting means the SOC contents in soil before transplanting. Difference between the columns with the same letter in the same soil depth is not significant at $P<0.05)$.

3.5. Leaching Risks of DOC. Ten-day deep seepage ranged from $2.3 \mathrm{~mm}$ to $46.2 \mathrm{~mm}$ in NFI fields, which was significantly lower than the corresponding values (from $7.2 \mathrm{~mm}$ to $72.6 \mathrm{~mm}$ ) in FI fields except in later June and middle October (Figure 5). Seasonal percolation in NFI paddies was $368.8 \mathrm{~mm}$, which was reduced by $42.9 \%$ compared with the FI treatment. Seasonal leaching loss of DOC was $63.3 \mathrm{~kg} \mathrm{C} \mathrm{ha}^{-1}$ from NFI soils, which was reduced by $46.4 \%$ compared with those from FI fields $\left(118.1 \mathrm{~kg} \mathrm{C} \mathrm{ha}^{-1}\right)$. Although DOC concentration in surface soil $(0-20 \mathrm{~cm})$ and soil solutions (7$14 \mathrm{~cm}$ ) was increased in NFI fields, the reduced percolation in the NFI fields led to lower risk of DOC leaching loss than in FI fields. Several studies focused on DOC losses from forest soil $[21,43]$. However, few studies on DOC leaching losses in rice paddies have been reported. In the current study, the seasonal leaching losses of DOC from FI paddies fell in the range reported by Katoh et al. (2004) [44] in typical rice fields in Japan ( 85 to $170 \mathrm{~kg} \mathrm{C} \mathrm{ha}^{-1}$ ). The seasonal DOC leaching losses of FI paddies were less than the lower limit of $85 \mathrm{~kg} \mathrm{C} \mathrm{ha}^{-1}$.
3.6. Soil Organic Carbon. SOC contents at harvest were reduced at $0-10$ and $10-20 \mathrm{~cm}$ depth for both treatments but increased at $20-40$ and $40-60 \mathrm{~cm}$ depth in the NFI and FI fields, respectively (Figure 6), but the reduction is insignificant in the short-term experiment except for $0-10 \mathrm{~cm}$ soil in NFI paddies. The SOC in different soil depth was calculated based on the SOC content (in Figure 6) and soil bulk density. The SOC storage in NFI paddies was reduced by 231 and $96 \mathrm{~g} \mathrm{~m}^{-2}$ at $0-10 \mathrm{~cm}$ and $10-20 \mathrm{~cm}$ depths but increased by 59 and $83 \mathrm{~g} \mathrm{~m}^{-2}$ at 20-40 and $40-60 \mathrm{~cm}$ depths. SOC storage in FI paddies was reduced by 118, 66, and $52 \mathrm{~g} \mathrm{~m}^{-2}$ at $0-10,10-20$, and $20-40 \mathrm{~cm}$, and increased by $161 \mathrm{~g} \mathrm{~m}^{-2}$ at $40-60 \mathrm{~cm}$. The obtained values confirm that long duration of nonflooding aerobic condition and wetdry cycles enhanced the soil organic decomposition and mineralization in paddy soils, leading to increased SOC loss $[45,46]$. Compared with FI paddies, less carbon was accumulated in deep soils $(40-60 \mathrm{~cm})$, and more SOC was lost in surface soils $(0-20 \mathrm{~cm})$ of NFI paddies. SOC content of NFI paddies indicate that more carbon was released into the atmosphere from surface soil than in FI paddies. A study regarding the greenhouse gas emission from NFI paddies [47] reported that seasonal $\mathrm{CH}_{4}$ emission from NFI paddies was $1.17-1.35 \mathrm{~g} \mathrm{~m}^{-2}$, which was much lower than that (6.62$7.20 \mathrm{~g} \mathrm{~m}^{-2}$ ) from FI paddies. Thus, we can deduce that more $\mathrm{CO}_{2}$ was released from NFI paddies than FI paddies because the aerobic condition favored carbon decomposition [45].

\section{Discussions}

4.1. Solubility and Mobility of Soil Organic Carbon. The long duration of nonflooding aerobic condition and multi-wetdry cycles in NFI enhanced the solubility of organic carbon in $0-20 \mathrm{~cm}$ soil (Figures 3 and 4). Several studies confirmed the effect of wet-dry cycles, oven drying, or air drying with incubation experiments by measuring the soil carbon mineralization rate, soil respiration, soil microbial biomass carbon [35, 37, 48-51], or soil DOC contents [52-54]. Higher WEOC contents in deep soils of 20-30, 30-40, and 40-60 cm in the FI fields indicate that more DOC was transferred from the topsoils to the deep soils due to high percolation rate (Table 2). The relationship between soil WEOC distribution in the soil profile and water flows was indicated by Mertens et al. (2007) [55] and Junod et al. (2009) [56] on arable soils. But DOC contents in deep soil solutions in NFI paddies were always lower than those in FI paddies (Figure 4). It indicated that downward moving of DOC was determined more by deep seepage volume than the DOC contents in surface soils.

4.2. Potential Environment Impacts. High WEOC and DOC contents in NFI soils are the consequence of the high microbial oxidative breakdown of soil organic matter and turnover of microbial biomass [2]. The high microbial activity in NFI soil will be accompanied with high soil respiration [57, 58], which led to greenhouse gas $\left(\mathrm{CO}_{2}\right.$ and $\left.\mathrm{CH}_{4}\right)$ emission. The lower SOC contents in NFI surface soil also confirmed it. Compared with FI paddies, less carbon was accumulated in deep soils $(40-60 \mathrm{~cm})$ and more SOC was lost in surface soils 
$(0-20 \mathrm{~cm})$ of NFI paddies (Figure 6), although the differences were mostly insignificant for one-year experiment in current research. If the NFI is applied to rice paddies in long-term, the effect on soil carbon pool and soil carbon output will be accumulated and get even significant. The reduced SOC content in NFI surface soils indicates that more carbon was released into the atmosphere from surface soil than in FI paddies. A study regarding the greenhouse gas emission from NFI paddies [47] reported that seasonal $\mathrm{CH}_{4}$ emission from NFI paddies was $1.17-1.35 \mathrm{~g} \mathrm{~m}^{-2}$, which was much lower than that $\left(6.62-7.20 \mathrm{~g} \mathrm{~m}^{-2}\right)$ from FI paddies. Thus, we can deduce that more $\mathrm{CO}_{2}$ was released from NFI paddies than FI paddies because the aerobic condition favored carbon decomposition [45]. The reduced percolation in the NFI fields also led to lower DOC leaching loss than in FI fields that is helpful to reduce the risk of groundwater pollution. In addition, solubility of SOC concentration (especially DOC content) is also an important factor for the translocation of trace metals [11-13] and organic compound pollutants [8-10]. Thus, soil respiration rate, SOC fractions, and translocation of heavy metals and organic compounds should be studied to help illustrate the ecoenvironment effect of water saving irrigation on rice paddies.

4.3. Soil Fertility and Sustainability. Generally, flooding condition in rice paddies frequently results in high SOC contents compared with the upland's seasonal soil carbon accumulation, or results in long-term SOC continuous accumulation [59-61]. As a result of enhanced decomposition and mineralization of SOC in NFI surface soil, SOC in surface NFI soil decreased. Long-term application of NFI in rice fields might lead to more release of carbon from surface soil and consequently lead to degradation in the soil fertility and sustainability. Thus, future studies should look into the combinations of water and carbon (residue or biochar) management practices to enhance soil carbon storage and soil sustainability in NFI rice paddies.

\section{Conclusions}

WEOC contents in soils and soil solutions, soil organic carbons, and DOC leaching risks were observed in rice paddies under different irrigation managements. The results indicated that long duration of nonflooding aerobic condition and wetdry cycles in NFI enhanced the soil organic decomposition and mineralization and consequently led to high solubility of SOC in surface soil. WEOC contents in soils and DOC in soil solution increased in NFI paddies in the surface soil layer but decreased in the deep soil layer. Less carbon moved downward to deep soils due to the decrease in percolation. The leaching losses of DOC in NFI fields were reduced by $46.4 \%$ compared with those from FI fields. SOC in surface soil was decreased in NFI paddies, indicating that more carbon was released into the atmosphere from the surface soil than in FI. The influence of irrigation management on soil organic carbon dynamics, soil respiration, and net $\mathrm{CO}_{2}$ exchange are important problems that should be discussed in future studies. Moreover, the influence on soil carbon fraction, which strongly related to changes in translocation of heavy metals and organic compounds, must also be considered.

\section{Authors' Contribution}

Junzeng Xu performed the data analysis and wrote the paper; Qi Wei and Xiaoli Gao contributed to the field experiment and laboratory assay; Shizhang Peng is the corresponding author, conceived, and designed the experiments; Shihong Yang contributed significantly to data analysis and paper preparation.

\section{Acknowledgments}

The research was financially supported by the National Natural Science Foundation of China (no. 51179051 and no. 51209066), the Fundamental Research Funds for the Central Universities (Program no. 2012B07514), and the Qinglan Project of Jiangsu Province.

\section{References}

[1] K. Kalbitz, S. Solinger, J.-H. Park, B. Michalzik, and E. Matzner, "Controls on the dynamics dissolved organic matter in soils: a review," Soil Science, vol. 165, no. 4, pp. 277-304, 2000.

[2] B. Michalzik, K. Kalbitz, J.-H. Park, S. Solinger, and E. Matzner, "Fluxes and concentrations of dissolved organic carbon and nitrogen-a synthesis for temperate forests," Biogeochemistry, vol. 52, no. 2, pp. 173-205, 2001.

[3] J. Iqbal, R. Hu, M. Feng, S. Lin, S. Malghani, and I. M. Ali, "Microbial biomass, and dissolved organic carbon and nitrogen strongly affect soil respiration in different land uses: a case study at Three Gorges Reservoir Area, South China," Agriculture, Ecosystems and Environment, vol. 137, no. 3-4, pp. 294-307, 2010.

[4] Y. Lu, R. Wassmann, H.-U. Neue, and C. Huang, "Dynamics of dissolved organic carbon and methane emissions in a flooded rice soil," Soil Science Society of America Journal, vol. 64, no. 6, pp. 2011-2017, 2000.

[5] M. Zhan, C. Cao, J. Wang et al., "Dynamics of methane emission, active soil organic carbon and their relationships in wetland integrated rice-duck systems in Southern China," Nutrient Cycling in Agroecosystems, vol. 89, no. 1, pp. 1-13, 2010.

[6] T. Filep and M. Rékási, "Factors controlling dissolved organic carbon (DOC), dissolved organic nitrogen (DON) and DOC/DON ratio in arable soils based on a dataset from Hungary," Geoderma, vol. 162, no. 3-4, pp. 312-318, 2011.

[7] M. L. A. Silveira, "Dissolved organic carbon and bioavailability of $\mathrm{N}$ and $\mathrm{P}$ as indicators of soil quality," Scientia Agricola, vol. 62, pp. 502-508, 2005.

[8] H. V. Mott, "Association of hydrophobic organic contaminants with soluble organic matter: evaluation of the database of Kdoc values," Advances in Environmental Research, vol. 6, no. 4, pp. 577-593, 2002.

[9] A. J. Sweetman, M. D. Valle, K. Prevedouros, and K. C. Jones, "The role of soil organic carbon in the global cycling of persistent organic pollutants (POPs): interpreting and modelling field data," Chemosphere, vol. 60, no. 7, pp. 959-972, 2005.

[10] E. González-Pradas, M. Fernández-Pérez, F. Flores-Céspedes et al., "Effects of dissolved organic carbon on sorption of 3,4-dichloroaniline and 4-bromoaniline in a calcareous soil," Chemosphere, vol. 59, no. 5, pp. 721-728, 2005. 
[11] Y. Yang, L. Liang, and D. Y. Wang, "Effect of dissolved organic matter on adsorption and desorption of mercury by soils," Journal of Environmental Sciences, vol. 20, no. 9, pp. 1097-1102, 2008.

[12] P. N. Williams, H. Zhang, W. Davison et al., "Organic mattersolid phase interactions are critical for predicting arsenic release and plant uptake in Bangladesh paddy soils," Environmental Science and Technology, vol. 45, no. 14, pp. 6080-6087, 2011.

[13] L. H. Wu, L. Zhu, A. Ikuko et al., "Effects of arganic amendments on $\mathrm{Cd}, \mathrm{Zn}$ and $\mathrm{Cu}$ bioavailability in soil with repeated phytoremediation by sedum plumbizincicola," International Journal of Phytoremediation, Vol, vol. 14, no. 10, pp. 1024-1038, 2012.

[14] S. Tao and B. Lin, "Water soluble organic carbon and its measurement in soil and sediment," Water Research, vol. 34, no. 5, pp. 1751-1755, 2000.

[15] M. D. Ruark, B. A. Linquist, J. Six et al., "Seasonal losses of dissolved organic carbon and total dissolved solids from rice production systems in northern California," Journal of Environmental Quality, vol. 39, no. 1, pp. 304-313, 2010.

[16] P. J. Hernes, R. G. M. Spencer, R. Y. Dyda, B. A. Pellerin, P. A. M. Bachand, and B. A. Bergamaschi, "The role of hydrologic regimes on dissolved organic carbon composition in an agricultural watershed," Geochimica et Cosmochimica Acta, vol. 72, no. 21, pp. 5266-5277, 2008.

[17] H. F. Wilson and M. A. Xenopolous, "Effects of agricultural land use on the composition of fluvial dissolved organic carbon," Nature Geoscience, vol. 2, pp. 37-41, 2009.

[18] L. Wang, C. Song, Y. Song, Y. Guo, X. Wang, and X. Sun, "Effects of reclamation of natural wetlands to a rice paddy on dissolved carbon dynamics in the Sanjiang Plain, Northeastern China," Ecological Engineering, vol. 36, no. 10, pp. 1417-1423, 2010.

[19] I. A. Janssens, A. Freibauer, P. Ciais et al., "Europe's terrestrial biosphere absorbs 7 to $12 \%$ of European anthropogenic $\mathrm{CO}_{2}$ emissions," Science, vol. 300, no. 5625, pp. 1538-1542, 2003.

[20] J. Siemens and I. A. Janssens, "The european carbon budget: a gap," Science, vol. 302, no. 5651, p. 1681, 2003.

[21] B. Gielen, J. Neirynck, S. Luyssaert, and I. A. Janssens, "The importance of dissolved organic carbon fluxes for the carbon balance of a temperate Scots pine forest," Agricultural and Forest Meteorology, vol. 151, no. 3, pp. 270-278, 2011.

[22] R. Kindler, J. Siemens, K. Kaiser et al., "Dissolved carbon leaching from soil is a crucial component of the net ecosystem carbon balance," Global Change Biology, vol. 17, no. 2, pp. 11671185, 2011.

[23] K. Kyuma, Paddy Soil Science, Kyoto University Press, Kyoto, Japan, 2004.

[24] B. K. Pathak, F. Kazama, and I. Toshiaki, "Monitoring of nitrogen leaching from a tropical paddy in Thailand," Journal of Scientific Research and Development, vol. 6, pp. 1-11, 2004.

[25] X. J. Xie, W. Ran, Q. R. Shen, C. Y. Yang, J. J. Yang, and Z. H. Cao, "Field studies on 32P movement and P leaching from flooded paddy soils in the region of Taihu Lake, China," Environmental Geochemistry and Health, vol. 26, no. 2, pp. 237-243, 2004.

[26] K. S. Yoon, J. K. Choi, J. G. Son, and J. Y. Cho, "Concentration profile of nitrogen and phosphorus in leachate of a paddy plot during the rice cultivation period in southern Korea," Communications in Soil Science and Plant Analysis, vol. 37, no. 13-14, pp. 957-972, 2006.

[27] X. Zhao, Y.-X. Xie, Z.-Q. Xiong, X.-Y. Yan, G.-X. Xing, and Z.-L. $\mathrm{Zhu}$, "Nitrogen fate and environmental consequence in paddy soil under rice-wheat rotation in the Taihu lake region, China," Plant and Soil, vol. 319, no. 1-2, pp. 225-234, 2009.
[28] S.-Z. Peng, S.-H. Yang, J.-Z. Xu, Y.-F. Luo, and H.-J. Hou, "Nitrogen and phosphorus leaching losses from paddy fields with different water and nitrogen managements," Paddy and Water Environment, vol. 9, no. 3, pp. 333-342, 2011.

[29] Z. Mao, Water efficient irrigation and environmentally sustainable irrigated rice production in China, International Commission on Irrigation and Drainage, http://www.icid.org/ wat_mao.pdf, 2001.

[30] W. A. Stoop, N. Uphoff, and A. Kassam, "A review of agricultural research issues raised by the system of rice intensification (SRI) from Madagascar: opportunities for improving farming systems for resource-poor farmers," Agricultural Systems, vol. 71, no. 3, pp. 249-274, 2002.

[31] D. F. Tabbal, B. A. M. Bouman, S. I. Bhuiyan, E. B. Sibayan, and M. A. Sattar, "On-farm strategies for reducing water input in irrigated rice; case studies in the Philippines," Agricultural Water Management, vol. 56, no. 2, pp. 93-112, 2002.

[32] P. Belder, B. A. M. Bouman, R. Cabangon et al., "Effect of watersaving irrigation on rice yield and water use in typical lowland conditions in Asia," Agricultural Water Management, vol. 65, no. 3, pp. 193-210, 2004.

[33] B. A. M. Bouman, R. M. Lampayan, and T. P. Tuong, Water Management in Irrigated Rice: Coping With Water Scarcity, International Rice Research Institute, Los Baños, Philippines, 2007.

[34] E. A. Davidson, "Sources of nitric oxide and nitrous oxide following wetting of dry soil," Soil Science Society of America Journal, vol. 56, no. 1, pp. 95-102, 1992.

[35] A. Prechtel, C. Alewell, B. Michalzik, and E. Matzner, "Different effect of drying on the fluxes of dissolved organic carbon and nitrogen from a Norway spruce forest floor," Journal of Plant Nutrition and Soil Science, vol. 163, no. 5, pp. 517-521, 2000.

[36] Z. Mao, "Water saving irrigation for rice and its effect on environment," Engineering Science, vol. 4, no. 7, pp. 8-16, 2002.

[37] S.-R. Xiang, A. Doyle, P. A. Holden, and J. P. Schimel, "Drying and rewetting effects on $\mathrm{C}$ and $\mathrm{N}$ mineralization and microbial activity in surface and subsurface California grassland soils," Soil Biology and Biochemistry, vol. 40, no. 9, pp. 2281-2289, 2008.

[38] S. T. Bao, Soil and Agro-Chemistry Analysis, Agricultural Press, Beijing, China, 2000.

[39] G. Guggenberger and W. Zech, "Sorption of dissolved organic carbon by ceramic P80 suction cups," Journal of Plant Nutrition and Soil Science, vol. 155, pp. 151-155, 1992.

[40] R. J. Cabangon, T. P. Tuong, E. G. Castillo et al., "Effect of irrigation method and N-fertilizer management on rice yield, water productivity and nutrient in typical lowland rice conditions in China," Paddy and Water Environment, vol. 2, no. 4, pp. 195-206, 2004.

[41] H. Li, X. Liang, Y. Chen, G. Tian, and Z. Zhang, "Ammonia volatilization from urea in rice fields with zero-drainage water management," Agricultural Water Management, vol. 95, no. 8, pp. 887-894, 2008.

[42] M. Zhan, C.-G. Cao, Y. Jiang, J.-P. Wang, L.-X. Yue, and M.L. Cai, "Dynamics of active organic carbon in a paddy soil under different rice farming modes," Chinese Journal of Applied Ecology, vol. 21, no. 8, pp. 2010-2016, 2010.

[43] K. Fujii, M. Uemura, C. Hayakawa et al., "Fluxes of dissolved organic carbon in two tropical forest ecosystems of East Kalimantan, Indonesia," Geoderma, vol. 152, no. 1-2, pp. 127-136, 2009. 
[44] M. Katoh, J. Murase, M. Hayashi, K. Matsuya, and M. Kimura, "Nutrient leaching from the plow layer by water percolation and accumulation in the subsoil in an irrigated paddy field," Soil Science and Plant Nutrition, vol. 50, no. 5, pp. 721-729, 2004.

[45] C. Yang, L. Yang, and Z. Ouyang, "Organic carbon and its fractions in paddy soil as affected by different nutrient and water regimes," Geoderma, vol. 124, no. 1-2, pp. 133-142, 2005.

[46] R. J. Buresh and S. M. Haefele, Changes in Paddy Soils Under Transition to Water-Saving and Diversified Cropping Systems, World Congress of Soil Science, Brisbane, Australia, 2010.

[47] H. J. Hou, S. Z. Peng, J. Z. Xu, S. H. Yang, and Z. Mao, "Seasonal variations of $\mathrm{CH}_{4}$ and $\mathrm{N}_{2} \mathrm{O}$ emissions in response to water management of paddy fields located in Southeast China," Chemosphere, vol. 89, no. 7, pp. 884-892, 2012.

[48] N. Fierer and J. P. Schimel, "Effects of drying-rewetting frequency on soil carbon and nitrogen transformations," Soil Biology and Biochemistry, vol. 34, no. 6, pp. 777-787, 2002.

[49] M. M. Mikha, C. W. Rice, and G. A. Milliken, "Carbon and nitrogen mineralization as affected by drying and wetting cycles," Soil Biology and Biochemistry, vol. 37, no. 2, pp. 339-347, 2005.

[50] D. L. Jones and V. B. Willett, "Experimental evaluation of methods to quantify dissolved organic nitrogen (DON) and dissolved organic carbon (DOC) in soil," Soil Biology and Biochemistry, vol. 38, no. 5, pp. 991-999, 2006.

[51] S.-H. Yao, B. Zhang, and F. Hu, "Soil biophysical controls over rice straw decomposition and sequestration in soil: the effects of drying intensity and frequency of drying and wetting cycles," Soil Biology and Biochemistry, vol. 43, no. 3, pp. 590-599, 2011.

[52] K. Kaiser, M. Kaupenjohann, and W. Zech, "Sorption of dissolved organic carbon in soils: effects of soil sample storage, soilto-solution ratio, and temperature," Geoderma, vol. 99, no. 3-4, pp. 317-328, 2001.

[53] S. Klitzke, Mobilization Mechanisms of Soluble and Dispersible Heavy Metals and Metalloids in Soils, Technischen Universität, Berlin, Germany, 2007.

[54] G. F. Koopmans and J. E. Groenenberg, "Effects of soil ovendrying on concentrations and speciation of trace metals and dissolved organic matter in soil solution extracts of sandy soils," Geoderma, vol. 161, no. 3-4, pp. 147-158, 2011.

[55] J. Mertens, J. Vanderborght, R. Kasteel et al., "Dissolved organic carbon fluxes under bare soil," Journal of Environmental Quality, vol. 36, no. 2, pp. 597-606, 2007.

[56] J. Junod, E. Zagal, M. Sandoval, R. Barra, G. Vidal, and M. Villarroel, "Effect of irrigation levels on dissolved organic carbon soil distribution and the depth mobility of chlorpyrifos," Chilean Journal of Agricultural Research, vol. 69, no. 3, pp. 435444, 2009.

[57] V. A. Orchard and F. J. Cook, "Relationship between soil respiration and soil moisture," Soil Biology and Biochemistry, vol. 15, no. 4, pp. 447-453, 1983.

[58] R. Mancinelli, S. Marinari, V. Di Felice, M. C. Savin, and E. Campiglia, "Soil property, $\mathrm{CO}_{2}$ emission and aridity index as agroecological indicators to assess the mineralization of cover crop green manure in a Mediterranean environment," Ecological Indicator, vol. 34, pp. 31-40, 2013.

[59] W. Zhang, Y.-Q. Yu, W.-J. Sun, and Y. Huang, "Simulation of soil organic carbon dynamics in Chinese rice paddies from 1980 to 2000," Pedosphere, vol. 17, no. 1, pp. 1-10, 2007.

[60] S. Nishimura, S. Yonemura, T. Sawamoto et al., "Effect of land use change from paddy rice cultivation to upland crop cultivation on soil carbon budget of a cropland in Japan," Agriculture, Ecosystems and Environment, vol. 125, no. 1-4, pp. 9-20, 2008.

[61] M. F. Pampolino, E. V. Laureles, H. C. Gines, and R. J. Buresh, "Soil carbon and nitrogen changes in long-term continuous lowland rice cropping," Soil Science Society of America Journal, vol. 72, no. 3, pp. 798-807, 2008. 

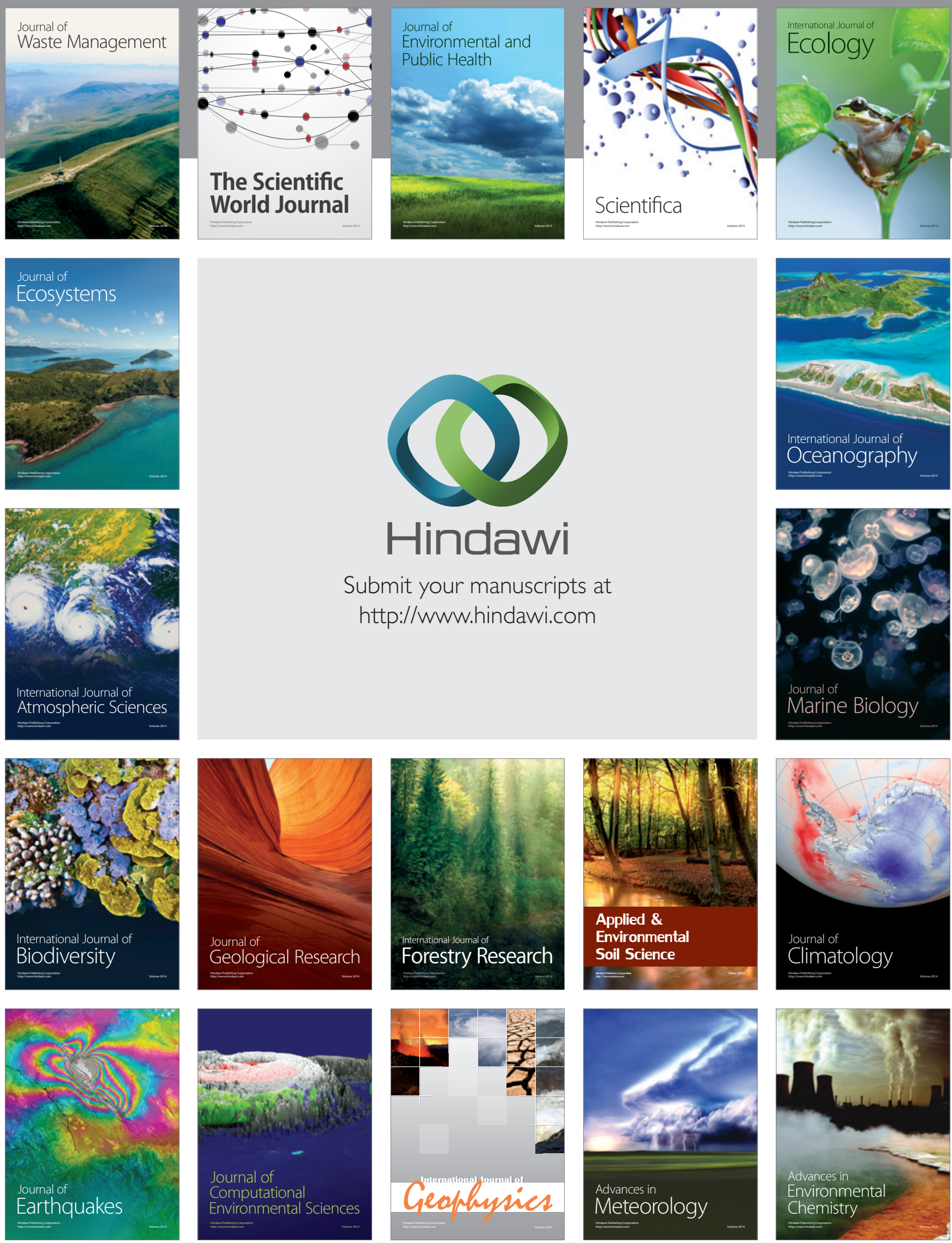